\title{
Interrelationship between cotton parameters and soil chemical properties in Central Brazil
}

\section{Inter-relação entre parâmetros do algodoeiro com atributos químicos do solo no Brasil Central}

\author{
Flávio Carlos Dalchiavon ${ }^{1, \star}$, Rosivaldo Hiolanda ${ }^{1}$, Daniel Dias Valadão Júnior ${ }^{1}$, \\ Franciele Caroline de Assis Valadã $0^{1}$, Morel de Passos e Carvalho ${ }^{2}$, Marcelo Andreotti ${ }^{2}$ \\ and Rafael Montanari² \\ ${ }_{1}^{1}$ Instituto Federal de Educação Ciência e Tecnologia de Mato Grosso-Campus Campo Novo do Parecis, curso de Bacharelado em Agronomia, MT 235, km 12, Zona Rural, \\ CEP 78360-000 Campo Novo do Parecis, MT, Brazil \\ 2 Universidade Estadual Paulista (UNESP), Faculdade de Engenharia (FE), Departamento de Fitossanidade, Engenharia Rural e Solos (DEFERS), Campus de Ilha Solteira, Brazil \\ ( ${ }^{\star} E-m a i l:$ flavio.dalchiavon@cnp.ifmt.edu.br) \\ http://dx.doi.org/10.19084/RCA17197
}

Received/recebido: 2017.08.03

Accepted/aceite: 2018.04 .16

\begin{abstract}
A B S T R A C T
Classical geostatistical techniques and Geostatistics are important tools to correlate, linearly and spatially, vegetal productivity with the soil properties. Spatial and Pearson correlations between the attributes of the cotton plant and the soil properties were used in Campo Novo do Parecis, State of Mato Grosso, Brazil, in 2015 to determine the variability of plant productivity and soil chemical properties in the Savannah of Mato Grosso. A geostatistical grid was established for collection of data of the soil and plant, with 100 sampling points, in a plot with cotton crop. Soil was classified a Typic Tropustox. The variability expressed by the coefficient of variation was predominantly low to moderate for all soil chemical properties and productive variables of cotton. The absence of spatial dependence for soil chemical properties, except $\mathrm{pH}$, indicated that spatial variations should be considered for soil sampling design. Kriging maps for the productive attributes of cotton showed that they have similar spatial distribution patterns in the crop. The productive attributes of the crop with direct relationship on the productivity of seed cotton were the number of reproductive branches and the boll mass, both linear and spatial.
\end{abstract}

Keywords: Brazilian agribusiness, geostatistics, Gossypium hirsutum, precision agriculture, soil fertility.

\section{R E S U M O}

Técnicas de estatística clássica bem como da geoestatística são ferramentas importantes para correlacionar, linear e espacialmente, a produtividade vegetal com os atributos do solo. Assim, no ano de 2015, em Campo Novo do Parecis, Mato Grosso, Brasil, foram empregadas correlações, espaciais e de Pearson, entre atributos da planta de algodão e químicos do solo, visando determinar a variabilidade da produtividade vegetal e de atributos químicos do solo no Cerrado mato-grossense. Para tanto, instalou-se a malha geoestatística para a coleta de dados do solo e da planta, com 100 pontos amostrais, num talhão com a cultura de algodão. O solo foi classificado como um Latossolo VermelhoAmarelo distrófico. A variabilidade expressa pelo coeficiente de variação foi predominantemente baixa a média para todas as variáveis de química do solo e produtivas do algodoeiro. A ausência de dependência espacial para os atributos químicos do solo, excetuando-se o pH, indicou que as variações espaciais devem ser consideradas para o planejamento de coleta de amostras de solo. Os mapas de krigagem para os atributos produtivos do algodoeiro revelaram que estes possuem semelhantes padrões de distribuição espacial na lavoura. Os atributos produtivos da lavora com relação direta na produtividade de algodão em caroço foram o número de ramos reprodutivos e a massa do capulho, tanto linear, quanto espacial.

Palavras-chave: agricultura de precisão, agronegócio brasileiro, fertilidade do solo, geoestatística, Gossypium hirsutum. 


\section{INTRODUCTION}

The favorable climatic conditions, the topography that allows the mechanization of agriculture, the governmental programs to encourage cotton cultivation, and especially, the intensive adoption of modern technologies, are the major factors that have driven the cultivation of cotton in the Brazilian Savannah, so that this biome has provided the highest national crop yields under dry conditions (Zonta et al., 2014).

According to data from CONAB (2017), it is estimated that the national production of seed cotton in the 2016/17 growing season will total 3550 thousand tons (10\% higher than the 2015/16 crop), and the State of Mato Grosso will participate with $75.8 \%$, or 2334 thousand tons $(6 \%$ higher than the previous harvest). The national area cultivated in Brazil will occupy 673.5 thousand hectares, with average yield estimated at $3922 \mathrm{~kg} \mathrm{ha}^{-1}$, while that of the State of Mato Grosso will be 3943 kg ha-1.

Information obtained through research has been decisive in providing technological support to agricultural development, ensuring better yields and competitive economic returns. Among the various technologies developed, the proper choice of the cultivar to the site of cultivation is one of the main components of the crop production system. The increase in crop productivity still necessarily requires mineral nutrition and the correct supply of essential elements that meet the requirements required in its phenological cycle (Dalchiavon et al., 2015).

Allied to the nutritional requirement of the crop, the application of inputs in general, which should be carried out with varied rates, is actually done in large areas in a homogeneous way, whether in Brazil, the United States of America (USA) or the rest of the world, disregarding the existence of spatial variability, which directly impacts the final cost of the crop, since among the main factors that define the profitability of a crop stand out productivity and production costs, in which the maximization of the efficiency of use of available resources allows the economic sustainability of the productive system (Stewart et al., 2005; Sana et al. 2014; Zonta et al., 2014), although according to Mooney et al. (2010), in cotton crops in 16 states in the USA, precision farming tools are used by $63 \%$ producers, but only $2 \%$ use productivity monitoring.

In support of these questions, the farmer has geostatistics at disposal, a tool that analyzes the spatial dependence of georeferenced data by the semivariogram adjustment, represented by the semivariance graph as a function of the distances between observations. Once the semivariance is obtained, the kriging map can be made for each attribute searched (soil and/or plant), which represents the spatial variability of the data. However, given the affinity between spatial dependencies of any two attributes, modeled by the cross-semivariogram, it can be obtained the cokriging map for the main attribute, usually difficult to obtain and of greater interest, according to a secondary attribute, usually easier to determine (Molin et al., 2007; Montanari et al., 2010; Dalchiavon et al., 2011). It would be possible, then, from the secondary attribute, to obtain spatially the estimates for the primary attribute as well as to suggest possible management interventions aiming at the primary attribute.

Currently, several studies have been carried out with the purpose of investigating the relationship between soil chemical properties (secondary) and crop productivity (principal), among them Dalchiavon et al. (2011, $2013 \mathrm{a}, \mathrm{b}, 2015)$ and Montanari et al. (2013), with the crops of beans, sugarcane, rice and sunflower, respectively. However, there is a shortage of studies on the cotton crop. Thus, it is essential that the research seeks to correlate cotton development with the chemical characteristics of the soil, focusing on the regions where the crop is intensively grown, such as is the case of the Savannah of Mato Grosso. In this context, the goal of this work was to determine the variability of cotton yield and soil chemical properties in the Savannah of Mato Grosso.

\section{MATERIAL AND METHODS}

The study was developed in 2015 at the Federal Institute of Mato Grosso (IFMT), Campo Novo do Parecis (State of Mato Grosso, Brazil), at

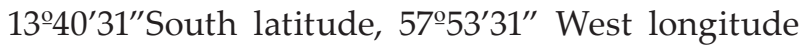
and $574 \mathrm{~m}$ altitude. The climate is $\mathrm{A}_{\mathrm{w}}$ (tropical humid with rainy season in summer and dry in winter). Figure 1 shows the values of rainfall and temperatures during the cultivation period. 


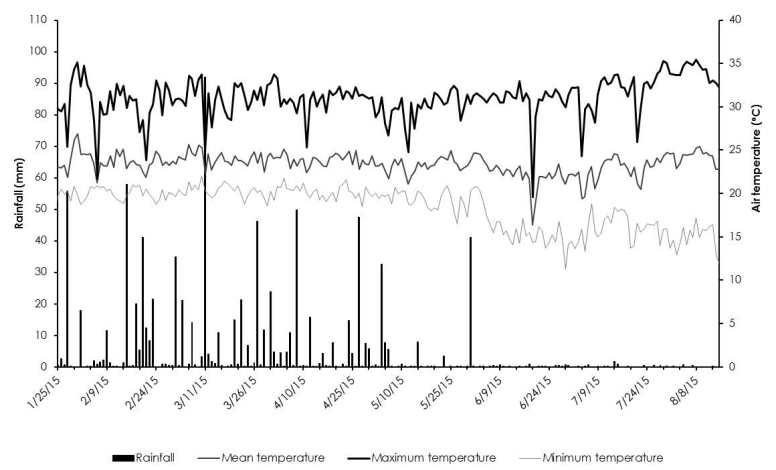

Figure 1 - Data on air temperature and cumulative rainfall in the experimental area during the conduction of the experiment (Campo Novo do Parecis, MT, 2015).

The soil was classified as Typic Tropustox, whose particle size at the $0-0.20 \mathrm{~m}$ layer was $506 \mathrm{~g} \mathrm{~kg}^{-1}$ clay, $134 \mathrm{~g} \mathrm{~kg}^{-1}$ silt and $360 \mathrm{~g} \mathrm{~kg}^{-1}$ sand. The initial chemical characterization of the soil at the $0-0.20 \mathrm{~m}$ layer showed the following values: $\mathrm{pH}\left(\mathrm{H}_{2} \mathrm{O}\right)=5.7$; $\mathrm{P}$ (resin) $=6.1 \mathrm{mg} \mathrm{dm}^{-3} ; \mathrm{K}=2.4 \mathrm{mmol} \mathrm{dm}^{-3} ; \mathrm{Ca}=$ $25 \mathrm{mmol}_{\mathrm{c}} \mathrm{dm}^{-3} ; \mathrm{Mg}=10 \mathrm{mmol}_{\mathrm{c}} \mathrm{dm}^{-3} ; \mathrm{Al}=0 \mathrm{mmol}_{\mathrm{c}} \mathrm{dm}^{-3}$; $\mathrm{H}+\mathrm{Al}=46 \mathrm{mmol}_{\mathrm{c}} \mathrm{dm}^{-3} ;$ Organic matter $=35.8 \mathrm{~g} \mathrm{dm}^{-3}$ and $\mathrm{V} \%=44.8 \%$.

In succession to soybean, in a plot of $10000 \mathrm{~m}^{2}(100$ x $100 \mathrm{~m}$ ), cotton (cultivar FM 940GLT, medium cycle, with 150 to 180 days) was sown on January 29, 2015, with $0.45 \mathrm{~m}$ between rows and seven seeds per meter, using as basal fertilization 200 kg ha-1 Monoammonium Phosphate (MAP: 12\% $\mathrm{N}$ and $52 \% \mathrm{P}_{2} \mathrm{O}_{5}$ ). On 06/03/2015 and 06/04/2015, 300 and $200 \mathrm{~kg} \mathrm{ha}^{-1}$ of the formulation 20-00-20 $\left(\mathrm{N}-\mathrm{P}_{2} \mathrm{O}_{5}-\mathrm{K}_{2} \mathrm{O}\right)$ was applied as complementary fertilizer, respectively. The control of pests, diseases and weeds was carried out as recommended for the crop, whenever necessary, through constant monitoring.

A grid was set up for data collection on July 25, 2015, and it consisted of 10 transects (NS direction), $10 \mathrm{~m}$ spaced apart, with 10 sampling points each, $8.5 \mathrm{~m}$ spaced apart, totaling 100 points distributed in an area of $91 \times 76 \mathrm{~m}$, the remainder was the border area. Between 25/07/2015 and 15/08/2015, the attributes (soil and plant) were collected at each sampling point.

The soil properties, at the $0-0.20 \mathrm{~m}$, were collected between the rows of the central point, being the levels of phosphorus $(\mathrm{P})$, organic matter $(\mathrm{OM}), \mathrm{pH}$ values $\left(\mathrm{CaCl}_{2}\right)$, content of potassium $(\mathrm{K})$, Calcium $(\mathrm{Ca})$, magnesium $(\mathrm{Mg})$, potential acidity $(\mathrm{H}+\mathrm{Al})$, sum of bases (SB), cation exchange capacity (T) and base saturation (V\%) determined, according to Raij et al. (2001), at the Laboratory of Physics and Soil Fertility of the Faculty of Engineering of Ilha Solteira (SP)/UNESP.

Plant attributes, seed cotton yield (CY, in $\left.\mathrm{kg} \mathrm{ha}^{-1}\right)$, plant population (PP, plants ha-1), final plant height (PH; m), stem diameter (SD), number of reproductive branches (RB), number of bolls per plant (BP), boll mass (BM; g), fiber mass of the boll (FM; g), seed mass of the boll (SM; g), percentage of fiber $(\% \mathrm{~F})$ and mass of 100 seeds (M100; g), were determined from the data collected in four rows of the culture with $1.80 \mathrm{~m}$, around each point.

$\mathrm{CY}$ for each point was estimated based on $3.24 \mathrm{~m}^{2}$ $(1.8 \times 1.8 \mathrm{~m})$, as well as for PP, with manual harvesting of bolls at physiological maturity $(90 \%$ open bolls), manual detachment of fibers and weighing. PH and SD were measured in a sample of five continuous plants of the useful area, from the base to the apex of the plant $(\mathrm{PH})$, with a ruler and $5 \mathrm{~cm}$ from the ground (SD), with digital caliper, at the moment of the harvest. RB was determined by the reproductive nodes; $\mathrm{BP}$, by counting the total number of bolls in the plant; BM by the mean of 30 bolls of the seed cotton; FM by BM minus SM; SM by $\mathrm{BM}$ minus $\mathrm{FM}$; $\% \mathrm{~F}$ by the relative mass of the fiber after the separation of the samples into FM and SM; and M100, obtained by the mass of 100 seeds ( $13 \%$ moisture).

Statistical analysis was performed with SAS and Excel spreadsheet, following the procedures of Dalchiavon et al. (2012a). The descriptive analysis of the attributes was performed, calculating the mean, median, minimum and maximum values, standard deviation, coefficient of variation, kurtosis, asymmetry and frequency distribution analysis by the Shapiro-Wilk test. A correlation matrix was constructed between all the attributes studied, containing all paired combinations possible, aiming to check for significant Pearson correlations between the attributes (dependent variables $x$ independent variables). Then, simple and multiple linear regressions of $\mathrm{CY}$ were performed according to the variables of the soil and/or plant, in order to determine which could 
serve as a quality indicator (s), when the objective was to increase CY.

For the geostatistical analysis, the Gamma Design Software 7.0 was used, following the procedures of Dalchiavon and Carvalho (2012). For each attribute, the spatial dependence was analyzed by the semivariogram, where adjustments were made primarily by the initial selection of: (a) the smallest sum of the squares of the deviations (RSS); (B) higher coefficient of determination $\left(\mathrm{r}^{2}\right)$; and (c) the highest spatial dependence evaluator (SDE). The interpretation proposed for SDE was also performed according to Dalchiavon and Carvalho (2012): a) SDE $<20 \%=$ spatial variable of very low dependence (MB); b) $20 \% \leq \mathrm{SDE}<40 \%=$ low dependence (BA); c) $40 \% \leq \mathrm{SDE}<60 \%=$ intermediate dependence (ME); d) $60 \% \leq \mathrm{SDE}<80 \%=$ high dependence (AL), and e) $80 \% \leq \mathrm{SDE}<100 \%$ $=$ very high dependence (MA). Cokrigings procedures were carried out, mainly those between $\mathrm{CY}$ and soil and/or plant attributes. The objective was to validate the existence of an attribute (soil and/or plant) that could spatially serve as an indicator of quality, that is, when the goal was to increase the seed cotton productivity.

\section{RESULTS AND DISCUSSION}

Because it is the typical representative of plant data, the normal (NO) frequency distribution (DF) is ideal for a statistical study (regression and/or geostatistical analysis). If this is not the case, normality is sought by logarithmic transformation (Molin et al., 2007). Table 1 illustrates that all attributes, except PH (IN) and M100 (TN), presented normal frequency distribution, whose coefficients of kurtosis and asymmetry ranged from -0.564 to 0.442 and -0.362 to 0.468 , respectively, which was expected as they are biological attributes (Montanari et al., 2010, 2013; Dalchiavon \& Carvalho, 2012; Dalchiavon et al., 2012, 2013a,c). Dalchiavon et al. (2015), studying the relationships of sunflower productivity with soil chemical properties by geostatistical techniques, have also found a DF of the type IN for $\mathrm{PH}$, which indicates that, for the attribute in question, it is common in studies of this nature.

There was low (FM, \% F and M100), intermediate (PP, PH, SD, BM and SM), high (CY and $\mathrm{RB}$ ) and very high (BP) data variability, analyzed by coefficient of variation (Table 1), differing from the data found by Carvalho et al. (2001) for the attributes $\mathrm{PH}, \mathrm{RB}, \mathrm{BP}, \mathrm{BM}$ and $\mathrm{CY}$, which may be related to

Table 1 - Descriptive analysis of production attributes of Gossypium hirsutum L. on a Typic Tropustox under no-till system. Campo Novo do Parecis (MT), 2015

\begin{tabular}{|c|c|c|c|c|c|c|c|c|c|c|}
\hline \multirow{3}{*}{ Attribute (a) } & \multirow{3}{*}{ Mean } & \multicolumn{9}{|c|}{ Descriptive statistical measures } \\
\hline & & \multirow{2}{*}{ Median } & \multicolumn{2}{|r|}{ Value } & \multirow{2}{*}{$\begin{array}{l}\text { Standard } \\
\text { deviation }\end{array}$} & \multirow[b]{2}{*}{$\begin{array}{c}\text { Variation } \\
(\%)\end{array}$} & \multicolumn{2}{|c|}{ Coefficient } & \multicolumn{2}{|c|}{$\begin{array}{l}\text { Probability of } \\
\text { the test } t^{(b)}\end{array}$} \\
\hline & & & Minimum & Maximum & & & Kurtosis & Asymmetry & $\operatorname{Pr}<w$ & DF \\
\hline CY $\left(\mathrm{kg} \mathrm{ha}{ }^{-1}\right)$ & 3096.0 & 3220.5 & 1263.4 & 4643.8 & 817.0 & 26.4 & -0.564 & -0.362 & 0.042 & $\mathrm{NO}$ \\
\hline PP & 142463 & 143519 & 94444 & 181482 & 17244 & 12.1 & -0.069 & -0.334 & 0.411 & $\mathrm{NO}$ \\
\hline $\mathrm{PH}(\mathrm{m})$ & 1.16 & 1.20 & 0.67 & 1.59 & 0.19 & 16.1 & 0.227 & -0.623 & $1.10^{-4}$ & IN \\
\hline $\mathrm{SD}(\mathrm{mm})$ & 12.23 & 12.36 & 7.60 & 15.73 & 1.74 & 14.2 & -0.099 & -0.303 & 0.383 & $\mathrm{NO}$ \\
\hline RB & 3.89 & 3.70 & 1.60 & 7.30 & 0.99 & 25.5 & 0.442 & 0.387 & 0.187 & $\mathrm{NO}$ \\
\hline $\mathrm{BP}$ & 4.84 & 4.65 & 1.70 & 8.70 & 1.55 & 32.2 & -0.227 & 0.468 & 0.052 & $\mathrm{NO}$ \\
\hline $\mathrm{BM}(\mathrm{g})$ & 4.06 & 4.06 & 3.15 & 5.15 & 0.42 & 10.4 & -0.248 & 0.075 & 0.773 & $\mathrm{NO}$ \\
\hline FM (g) & 2.13 & 2.12 & 1.66 & 2.66 & 0.21 & 9.9 & -0.349 & 0.048 & 0.856 & $\mathrm{NO}$ \\
\hline $\mathrm{SM}(\mathrm{g})$ & 1.93 & 1.93 & 1.46 & 2.50 & 0.23 & 11.7 & -0.169 & 0.174 & 0.589 & $\mathrm{NO}$ \\
\hline$\% \mathrm{~F}$ & 52.58 & 52.40 & 50.50 & 55.10 & 1.02 & 2.0 & -0.214 & 0.289 & 0.106 & $\mathrm{NO}$ \\
\hline M100 (g) & 7.36 & 7.33 & 6.30 & 8.97 & 0.48 & 6.5 & 1.088 & 0.487 & 0.023 & $\mathrm{TN}$ \\
\hline
\end{tabular}

(a) $\mathrm{CY}, \mathrm{PP}, \mathrm{PH}, \mathrm{SD}, \mathrm{RB}, \mathrm{BP}, \mathrm{BM}, \mathrm{FM}, \mathrm{SM}, \% \mathrm{~F}$ and $\mathrm{M} 100$ are, respectively, the productivity of seed cotton, plant population, plant height, stem diameter, number of reproductive branches, number of bolls per plant, boll mass, fiber mass per boll, seed mass per boll, percentage of fiber and mass of one hundred seed; (b) DF = frequency distribution, in which NO, IN and TN respectively of the types normal, indeterminate and tending to normal. 
the fact that these authors used nitrogen and potassium fertilization in cotton, while for $\% \mathrm{~F}$, data were similar. However, data were close to those obtained by Henrique and Laca-Buendía (2010), when they studied the morphological and agronomic characteristics of cotton, reporting low (SM, $\mathrm{M} 100, \% \mathrm{~F}$ and BM), intermediate (SD and PP), high ( $\mathrm{PH}$ and $\mathrm{BP}$ ) and very high $(\mathrm{CY}) \mathrm{CV}$. On the other hand, in a study carried out in eight cotton crops in the State of Texas (USA), the CV of CY varied between 8 and 32\% (Guo et al., 2012), consistent with the present study.

CY (3096 kg ha-1; Table 1) was low when compared to the $4000.0 \mathrm{~kg} \mathrm{ha}^{-1}$ reported by Sana et al. (2014) and to the $6285 \mathrm{~kg} \mathrm{ha}^{-1}$ of Santos et al. (2012) in Savannah soil, but was superior to $\mathrm{CY}$ reported by Kaneko et al. (2014) of $2507 \mathrm{~kg} \mathrm{ha}^{-1}$. These data demonstrate that $\mathrm{CY}$ can vary widely, depending on several factors, such as genotype and management, even within a single biome. The low CY obtained in this study is related both to the difficulty of weed control at post-emergence, which caused competition for the available environmental resources, and the low water availability at specific moments (Figure 1) due to the delay in crop sowing, which for the region is recommended until January $5^{\text {th }}$.

The other mean values of the attributes of the plants were, respectively, 142463 plants ha-1 $^{-1} 1.16 \mathrm{~m}$;
$12.23 \mathrm{~mm} ; 3.86 ; 4.84 ; 4.06 \mathrm{~g}, 2.13 \mathrm{~g}, 1.93 \mathrm{~g} ; 52.58 \%$ and $7.36 \mathrm{~g}$ for PP, PH, SD, RB, BP, BM, FM, SM, \%F and M100 (Table 1). These data are similar to those observed by Teixeira et al. (2008), with PP of 130000 plants ha-1, with PH of $1.20 \mathrm{~m}$ and M100 of $9.2 \mathrm{~g}$, of Henrique and Laca-Buendía (2010), with SD of $10.8 \mathrm{~mm}$, BP of 3.81, FM of $2.21 \mathrm{~g}$, SM of $3.07 \mathrm{~g}$, \% F of 41.36 and BM of $5.35 \mathrm{~g}$ of Motomiya et al. (2011), with PH of $1.20 \mathrm{~m}$ and PP of 122663 plants ha-1. $^{-1}$

For the soil properties (Table 2), it was observed $\mathrm{DF}$ in $\mathrm{NO}(\mathrm{OM}, \mathrm{pH}, \mathrm{K}, \mathrm{Ca}, \mathrm{Mg}, \mathrm{SB}, \mathrm{T}$ and $\mathrm{V} \%)$ and IN ( $\mathrm{P}$ and $\mathrm{H}+\mathrm{Al})$, agreeing with the data observed by Zonta et al. (2014) and Dalchiavon et al. (2015). In general, the coefficients of variation were between low $(\mathrm{OM}, \mathrm{pH}$ and $\mathrm{T})$, moderate $(\mathrm{Ca}, \mathrm{H}+\mathrm{Al}, \mathrm{SB}$ and $\mathrm{V} \%)$, high $(\mathrm{Mg})$ and very high ( $\mathrm{P}$ and $\mathrm{K}$ ), consistent with Motomiya et al. (2011) and Dalchiavon et al. (2015) for P and $\mathrm{K}$ and with Sana et al. (2014) for soil $\mathrm{pH}$ when they analyzed the variability of soil properties and their effects on cotton productivity.

The coefficients of kurtosis between -0.377 and 0.518 and those of asymmetry between -0.140 and 0.352 (Table 2), resemble those of DF and coefficients of variation mentioned by Dalchiavon et al. (2012, 2013a,b) and Montanari et al. (2013). In relation to soil fertility, and considering the mean/ median values of its chemical properties, it can be verified that these presented low $(\mathrm{K})$, moderate

Table 2 - Descriptive analysis of chemical properties of a Typic Tropustox cultivated with Gossypium hirsutum L. under no-till system. Campo Novo do Parecis (MT), 2015

\begin{tabular}{|c|c|c|c|c|c|c|c|c|c|c|}
\hline \multirow{3}{*}{ Properties ${ }^{(a)}$} & \multicolumn{10}{|c|}{ Descriptive statistical measures } \\
\hline & \multirow{2}{*}{ Mean } & \multirow{2}{*}{ Median } & \multicolumn{2}{|c|}{ Value } & \multirow{2}{*}{$\begin{array}{l}\text { Standard } \\
\text { deviation }\end{array}$} & \multicolumn{3}{|c|}{ Coefficient } & \multicolumn{2}{|c|}{$\begin{array}{c}\text { Probability of } \\
\text { the test }\end{array}$} \\
\hline & & & Minimum & Maximum & & $\begin{array}{c}\text { Variation } \\
(\%)\end{array}$ & Kurtosis & Asymmetry & $\operatorname{Pr}<w$ & DF \\
\hline $\mathrm{P}\left(\mathrm{mg} \mathrm{dm}^{-3}\right)$ & 17.1 & 16.0 & 10.0 & 48.0 & 6.5 & 38.0 & 8.160 & 2.626 & $1.10^{-4}$ & IN \\
\hline $\mathrm{OM}\left(\mathrm{g} \mathrm{dm}^{-3}\right)$ & 27.8 & 28.0 & 23.0 & 34.0 & 2.2 & 7.9 & -0.235 & 0.099 & 0.066 & $\mathrm{NO}$ \\
\hline $\mathrm{pH}$ & 5.4 & 5.4 & 4.8 & 6.0 & 0.3 & 5.0 & -0.093 & -0.054 & 0.050 & $\mathrm{NO}$ \\
\hline $\mathrm{K}\left(\mathrm{mmol}_{\mathrm{c}} \mathrm{dm}^{-3}\right)$ & 1.4 & 1.4 & 0.4 & 2.7 & 0.5 & 32.4 & -0.377 & 0.338 & 0.069 & $\mathrm{NO}$ \\
\hline $\mathrm{Ca}\left(\mathrm{mmol}_{\mathrm{c}} \mathrm{dm}^{-3}\right)$ & 23.0 & 23.0 & 12.0 & 34.0 & 4.4 & 19.0 & 0.138 & 0.021 & 0.581 & $\mathrm{NO}$ \\
\hline $\mathrm{Mg}\left(\mathrm{mmol}_{\mathrm{c}} \mathrm{dm}^{-3}\right)$ & 16.1 & 16.3 & 7.0 & 28.0 & 3.9 & 24.1 & 0.518 & 0.337 & 0.124 & $\mathrm{NO}$ \\
\hline $\mathrm{H}+\mathrm{Al}\left(\mathrm{mmol}_{\mathrm{c}} \mathrm{dm}^{-3}\right)$ & 29.7 & 28.0 & 18.0 & 42.0 & 5.8 & 19.4 & -0.271 & 0.219 & 0.002 & IN \\
\hline $\mathrm{SB}\left(\mathrm{mmol}_{\mathrm{c}} \mathrm{dm}^{-3}\right)$ & 40.3 & 41.0 & 20.0 & 60.0 & 8.0 & 19.8 & 0.218 & 0.134 & 0.425 & $\mathrm{NO}$ \\
\hline $\mathrm{T}\left(\mathrm{mmol}_{\mathrm{c}} \mathrm{dm}^{-3}\right)$ & 70.3 & 70.8 & 58.0 & 85.0 & 5.3 & 7.5 & 0.402 & 0.352 & 0.385 & $\mathrm{NO}$ \\
\hline $\mathrm{V} \%(\%)$ & 57.6 & 57.5 & 34.0 & 80.0 & 9.6 & 16.6 & 0.087 & -0.140 & 0.676 & $\mathrm{NO}$ \\
\hline
\end{tabular}

(a) $\mathrm{P}, \mathrm{OM}, \mathrm{pH}, \mathrm{K}, \mathrm{Ca}, \mathrm{Mg}, \mathrm{H}+\mathrm{Al}, \mathrm{SB}, \mathrm{T}$ and $\mathrm{V} \%$ are, respectively, phosphorus, organic matter, potential of hydrogen, potassium, calcium, magnesium, potential acidity, sum of bases, cation exchange capacity and base saturation; (b) DF = frequency distribution, with IN and NO, respectively, of the types indeterminate and normal. 
( $\mathrm{P}, \mathrm{OM}, \mathrm{pH}, \mathrm{V} \%)$ and high $(\mathrm{Ca}, \mathrm{Mg}, \mathrm{SB})$ values/ contents, according to the limits mentioned in Raij et al. (1997) and in Alves et al. (2009), also justifying, and partly, this CY. These values of soil chemical properties ( $\mathrm{K}, \mathrm{OM}, \mathrm{V} \%, \mathrm{Ca}$ and $\mathrm{Mg}$ ) were in accordance with those presented by Dalchiavon et al. (2012), when investigated the spatial variability of fertility attributes of a Typic Acrustox under no-till system in Selvíria (MS) and Zonta et al. (2014), when evaluating the spatial variability of soil fertility in the area planted with cotton in the Brazilian Savannah.

Pearson's significant correlations (plant $\mathrm{x}$ plant; plant $x$ soil), and of interest, for the pairs of attributes were: 1) CY x PP $\left.\left(\mathrm{r}=0.309^{* *}\right), 2\right) \mathrm{CY} \times \mathrm{SD}(\mathrm{r}$ $\left.=0.306^{* *}\right)$, 3) $\mathrm{CY} \times \mathrm{RB}\left(\mathrm{r}=0.553^{* *}\right)$, 4) $\mathrm{CY} \times \mathrm{BP}(\mathrm{r}=$ $\left.0.558^{* *}\right)$, 5) $\left.\mathrm{CY} \times \mathrm{BM}\left(\mathrm{r}=0.334^{* *}\right), 6\right) \mathrm{CY} \times \mathrm{FM}(\mathrm{r}=$ $\left.\left.\left.0.275^{* *}\right), 7\right) \mathrm{CY} \times \mathrm{SM}\left(\mathrm{r}=0.369^{* *}\right), 8\right) \mathrm{RB} \times \mathrm{PH}(\mathrm{r}=$ $\left.0.425^{* *}\right)$, 9) $\left.\mathrm{BP} \times \mathrm{PH}\left(\mathrm{r}=0.426^{* *}\right), 10\right) \% \mathrm{~F} \times \mathrm{PH}(\mathrm{r}=$ $\left.\left.\left.-0.253^{*}\right), 11\right) \mathrm{BP} \times \mathrm{RB}\left(\mathrm{r}=0.951^{* *}\right), 12\right) \mathrm{CY} \times \mathrm{OM}(\mathrm{r}=$ $\left.0.503^{* *}\right)$, 13) CY $\times \mathrm{T}\left(\mathrm{r}=0.238^{*}\right)$, 14) $\mathrm{PH} \times \mathrm{P}\left(\mathrm{r}=0.225^{*}\right)$, 15) $\mathrm{RB} \times \mathrm{OM}\left(\mathrm{r}=0.312^{* *}\right)$, 16) BP $\times \mathrm{OM}\left(\mathrm{r}=0.290^{* *}\right)$, 17) $\mathrm{FM} \times \mathrm{H}+\mathrm{Al}\left(\mathrm{r}=-0.206^{*}\right)$, 18) $\mathrm{M} 100 \times \mathrm{H}+\mathrm{Al}(\mathrm{r}=$ $-0.208^{*}$. It was observed that $83 \%$ of the correlations showed a direct cause-effect behavior, that is, any change in the values of the independent variables $(X)$ promoted a change of the same nature in the response or dependent variable $(\mathrm{Y})$.

The correlation coefficients between the plant attributes were high $(\mathrm{p}<0.01)$ and positive, except for $\%$ $\mathrm{F} \times \mathrm{PH}$, denoting an appreciable direct relationship between the attributes involved. $\mathrm{OM}$ and $\mathrm{T}$ were the only soil properties significant with CY, with low correlation coefficients, however positive, due basically to the fact that it is a classic example of a dependent variable (CY) against independent (OM and $\mathrm{T}$ ) and also due to the high number of observations $(\mathrm{n}=100)$, common in geostatistical studies, as reported by several researchers (Molin et al., 2007; Dalchiavon et al., 2013a,b; Montanari et al., 2013; Dalchiavon et al., 2015). Thus, the adjusted regression equations are listed in Tables 3 and 4.

Equations 1, 2, 3 and 4 (plant $\mathrm{x}$ plant; Table 3) revealed direct linear influence of $\mathrm{PP}, \mathrm{SD}, \mathrm{RB}$ and $\mathrm{BP}$ on $\mathrm{CY}$. Equations 5, 6, 7 and 11, although direct (except for \%F $x \mathrm{PH}$ ), presented potential models between the independent attributes (PH and $\mathrm{RB}$ ) and the dependent variables $(\mathrm{CY}, \% \mathrm{~F}, \mathrm{BP}$ and $\mathrm{RB})$. Exponential equations ( 8 to 10 ) were observed between CY (dependent) and BM, FM and SM (independent). Among the equations that aim to estimate CY, 4 was the one that provided the best fit (higher $r^{\prime \prime}$ ), and is therefore the most recommended for its estimation. Thus, by working in the mentioned equation, it is possible to estimate a $\mathrm{CY}$ of $3085.8 \mathrm{~kg} \mathrm{ha}^{-1}$, when BP is $4.84 \mathrm{~g}$ (Table 1), that is, with the increase in the number of bolls in the plant, because of larger viability, in this population and crop spacing, it can be estimated the seed cotton yield in a linear way.

On the other hand, 12 and 13 were linear equations (plant x soil; Table 4). However, quadratic (14),

Table 3 - Simple linear regression equation and adjustment coefficients between production attributes of Gossypium hirsutum L under a Typic Tropustox under no-till system. Campo Novo do Parecis (MT), 2015

\begin{tabular}{|c|c|c|c|c|c|c|}
\hline \multirow{2}{*}{ Mathematical model (a) } & \multicolumn{5}{|c|}{ Coefficient of adjustment ${ }^{(b)}$} & \multirow{2}{*}{ Equation number } \\
\hline & $\mathbf{a}$ & b & c & $\mathbf{r}$ & $\mathbf{r}^{2}$ & \\
\hline$C Y=a+b \cdot P P$ & 1004.252 & $1.468 .10^{-2 * *}$ & - & $0.310^{* *}$ & - & (1) \\
\hline$C Y=a+b \cdot S D$ & 1336.535 & $143.846^{* *}$ & - & $0.307^{* *}$ & - & (2) \\
\hline$C Y=a+b \cdot R B$ & 1324.727 & $455.819^{* *}$ & - & $0.552^{* *}$ & - & (3) \\
\hline$C Y=a+b \cdot B P$ & 1678.835 & $293.114^{* *}$ & - & $0.558^{* *}$ & - & (4) \\
\hline $\mathrm{CY}=\mathrm{a} \cdot \mathrm{PH}^{\mathrm{b}}$ & 4.058 & $9.007 .10^{-1 * *}$ & - & $0.473^{* *}$ & - & (5) \\
\hline$\% \mathrm{~F}=\mathrm{a} \cdot \mathrm{PH}^{\mathrm{b}}$ & 52.785 & $-2.918 .10^{-2 * *}$ & - & $0.261^{* *}$ & - & (6) \\
\hline $\mathrm{BP}=\mathrm{a} \cdot \mathrm{RB}^{\mathrm{b}}$ & 0.923 & $1.211^{* *}$ & - & $0.962^{* *}$ & - & (7) \\
\hline $\mathrm{CY}=\mathrm{a} \cdot \mathrm{EXP}$ вм.b & 1090.907 & $2.470 .10^{-1 * *}$ & - & $0.346^{* *}$ & - & (8) \\
\hline $\mathrm{CY}=\mathrm{a} \cdot \mathrm{EXP}$ FM.b & 1222.804 & $4.178 .10^{-1 * *}$ & - & $0.292^{* *}$ & - & (9) \\
\hline$C Y=a \cdot E X P$ SM.b & 1131.942 & $4.996 .10^{-1 * *}$ & - & $0.376^{* *}$ & - & (10) \\
\hline $\mathrm{RB}=\mathrm{a} \cdot \mathrm{PH}^{\mathrm{b}}$ & 3.422 & $6.900 .10^{-1 * *}$ & - & $0.455^{* *}$ & - & (11) \\
\hline
\end{tabular}

(a) CY, PP, PH, SD, RB, BP, BM, FM, SM and \%F are, respectively, the productivity of seed cotton, plant population, plant height, stem diameter, number of reproductive branches, number of bolls per plant, boll mass, fiber mass per boll, seed mass per boll and percentage of fiber; ${ }^{(b) * *}=$ significant at $1 \%^{*}$ 
Table 4 - Simple linear regression equation and adjustment coefficients between production attributes of Gossypium hirsutum $\mathrm{L}$ and properties of a Typic Tropustox under no-till system. Campo Novo do Parecis (MT), 2015

\begin{tabular}{|c|c|c|c|c|c|c|}
\hline \multirow{2}{*}{ Mathematical model (a) } & \multicolumn{5}{|c|}{ Coefficient of adjustment ${ }^{(b)}$} & \multirow{2}{*}{$\begin{array}{l}\text { Equation } \\
\text { number }\end{array}$} \\
\hline & a & b & c & $\mathbf{r}$ & $\mathbf{r}^{2}$ & \\
\hline $\mathrm{CY}=\mathrm{a}+\mathrm{b} \cdot \mathrm{OM}$ & -2086.903 & $186.236^{* *}$ & - & $0.503^{* *}$ & - & (12) \\
\hline $\mathrm{CY}=\mathrm{a}+\mathrm{b} . \mathrm{T}$ & 494.354 & 36.997 & - & $0.238^{*}$ & - & (13) \\
\hline $\mathrm{PH}=\mathrm{a}+\mathrm{b} \cdot \mathrm{P}+\mathrm{c} \cdot \mathrm{P}^{2}$ & $7.375 .10^{-1}$ & $3.619 .10^{-2 * *}$ & $5.829 .10^{-4^{*}}$ & - & $0.103^{* *}$ & (14) \\
\hline $\mathrm{RB}=\mathrm{a} \cdot \mathrm{OM}^{\mathrm{b}}$ & $1.073 .10^{-1}$ & $1.070^{* *}$ & - & $0.322^{* *}$ & - & (15) \\
\hline $\mathrm{BP}=\mathrm{a} \cdot \mathrm{OM}^{\mathrm{b}}$ & $5.619 .10^{-2}$ & $1.325^{* *}$ & - & $0.317^{* *}$ & - & (16) \\
\hline $\mathrm{FM}=\mathrm{a} \cdot \mathrm{EXP}$ HAl.b & 2.357 & $-3.631 .10^{-3^{*}}$ & - & $0.210^{*}$ & - & (17) \\
\hline $\mathrm{M} 100=\mathrm{a} \cdot \mathrm{HAl}^{\mathrm{b}}$ & 9.376 & $-7.231 .10^{-2^{*}}$ & - & $0.221^{*}$ & - & (18) \\
\hline
\end{tabular}

(a) $\mathrm{CY}, \mathrm{PH}, \mathrm{BP}, \mathrm{FM}, \mathrm{M} 100 \mathrm{P}, \mathrm{OM}, \mathrm{H}+\mathrm{Al}$, and T are, respectively, the productivity of seed cotton, plant height, number of bolls per plant, boll mass, fiber mass per boll, 100 -seed mass and content of phosphorus, organic matter, pot ential of hydrogen and cation exchange capacity; (b) $* \star$ and $*=$ significant at $1 \%$ and $5 \%$, respectively.

potential (15, 16 and 18) and exponential (17) equations were also modeled. OM and T, as mentioned above, were the only soil properties indicated to estimate CY, which would be 3096 and $3095 \mathrm{~kg} \mathrm{ha}^{-1}$ when $\mathrm{OM}$ and $\mathrm{T}$ contents were, respectively, 27.83 $\mathrm{g} \mathrm{dm}^{-3}$ and $70.3 \mathrm{mmol}_{\mathrm{c}} \mathrm{dm}^{-3}$ (Table 1). In this way, conservationist soil management, such as no-till systems, which aim to increase organic matter contents, and will directly and positively implicate their $\mathrm{T}$, are necessary to obtain higher seed cotton yields, by increasing fertility through nutrient cycling $(\mathrm{OM})$ and the maintenance of exchangeable bases available in soils usually dependent on $\mathrm{T}$ by increase in OM contents, since the other colloids in Savannah soils have low expressiveness in $\mathrm{T}$ values and are very dependent on $\mathrm{pH}$.

The geostatistical analysis (Table 5) revealed, for the plant attributes that did not result in pure nugget effect, that the decreasing order of the spatial correlation coefficients ( $\left.\mathrm{r}^{2}\right)$ was: 1$\left.) \mathrm{PH}(0.888), 2\right) \% \mathrm{~F}$ (0.851), 3) SD (0.818), 4) FM (0.596), 5) BM (0.587), 6) SM (0.521), 7) \#CY (0.508) and 8) RB (0.504). The $\mathrm{PH}$ derived in a very high spatial correlation coefficient $\left(\mathrm{r}^{2}\right)$, very high spatial dependency (SDE) $(87.2 \%)$ and angular coefficient (b) of the cross-validation near 1 (1.022), denoting high quality of the experimental semivariogram of spherical type, thus agreeing with the semivariographic model reported by Motomiya et al. (2011), who proposed a diagnosis for the localized management of the cotton crop, and mentioned high $\mathrm{r}^{2}(0.640)$ and high $\operatorname{SDE}(68.0 \%)$.

In relation to the pure nugget effect for $\mathrm{BP}$ and M100 (Table 5), this is relatively common because they are productive attributes related to cotton maturity, which are heavily influenced by the environment (Johnson et al., 2002).

\#CY, attribute of greater agronomic interest, presented semivariographic spherical model, intermediate $\mathrm{r}^{2}(0.508)$, very high SDE $(99.8 \%)$ and angular coefficient of cross validation of 0.983 (Table 5). Motomiya et al. (2011) obtained spherical model, intermediate $\mathrm{r}^{2}(0.500)$ and high SDE $(70.0 \%)$, while Sana et al. (2014) reported spherical model, intermediate $\mathrm{r}^{2}$ and very high SDE, therefore, both studies corroborate the data of the present research.

Regarding soil properties, only $\mathrm{pH}$ showed spatial dependence (Table 5). The pure nugget effect for the other soil properties indicated that the behavior of these regionalized variables was totally random, revealing the semivariogram discontinuity for distances smaller than those sampled, indicating the need to rethink this distance, which was evidenced in the study by Dalchiavon et al. (2013b). Motomiya et al. (2011) also found no spatial dependence for $\mathrm{P}$ and $\mathrm{Mg}$, denoting that the spatial dependence of soil properties can also vary according to the area and the management applied. Typically, in areas under no-till system, as nutrient application vary from spreading and in-row, in crops with different spacings, combined with high or low nutrient mobility, heterogeneity becomes common, and semivariogram adjustments do not always have quality because of lower ranges.

$\mathrm{pH}$ (Table 5), with a Gaussian semivariogram model, had a low spatial correlation coefficient (0.399), intermediate spatial dependence (57.3\%) and an angular coefficient of 0.881 , demonstrating 
Table 5 - Parameters of the simple and cross semivariograms adjusted for productive attributes of Gossypium hirsutum L. and chemical properties of a Typic Tropustox under no-till system. Campo Novo do Parecis (MT), 2015

\begin{tabular}{|c|c|c|c|c|c|c|c|c|c|c|c|}
\hline \multirow{3}{*}{ Attribute $^{(a)}$} & \multicolumn{11}{|c|}{ Adjustment parameters } \\
\hline & \multirow{2}{*}{ Model $^{(\mathfrak{b})}$} & \multirow[b]{2}{*}{$\mathrm{C}_{\mathrm{o}}$} & \multirow[b]{2}{*}{$\mathrm{C}_{\mathrm{o}}+\mathrm{C}$} & \multirow{2}{*}{$\begin{array}{l}\mathbf{A}_{\mathrm{o}} \\
(\mathrm{m})\end{array}$} & \multirow{2}{*}{$\mathbf{r}^{2}$} & \multirow{2}{*}{$\mathrm{SQR}^{(\mathrm{c})}$} & \multicolumn{2}{|c|}{ SDE(d) } & \multicolumn{3}{|c|}{ Cross-validation } \\
\hline & & & & & & & $\%$ & Class & a & $\mathbf{b}$ & $\mathbf{r}$ \\
\hline \multicolumn{12}{|c|}{$\gamma(h)$ simple - plant } \\
\hline$\# \mathrm{CY}$ & esf (136) & $1.10 .10^{3}$ & $4.43 .10^{5}$ & 26.4 & 0.508 & $6.54 .10^{10}$ & 99.8 & MA & -9.45 & 0.983 & 0.764 \\
\hline$\# \mathrm{PP}$ & epp & $2.99 .10^{8}$ & $2.99 .10^{8}$ & - & - & - & - & - & - & - & - \\
\hline $\mathrm{PH}$ & $\exp (126)$ & $3.77 .10^{-4}$ & $2.95 .10^{-2}$ & 31.8 & 0.888 & $2.02 .10^{-5}$ & 87.2 & MA & $-2.00 .10^{-2}$ & 1.022 & 0.554 \\
\hline SD & $\exp (137)$ & $2.86 .10^{-1}$ & 2.14 & 17.7 & 0.818 & $4.58 .10^{-2}$ & 86.6 & MA & $8.50 .10^{-1}$ & 0.933 & 0.303 \\
\hline $\mathrm{RB}$ & $\exp (126)$ & $1.19 .10^{-1}$ & $7.55 .10^{-1}$ & 20.1 & 0.344 & $6.74 .10^{-2}$ & 84.2 & MA & 1.64 & 0.576 & 0.219 \\
\hline $\mathrm{BP}$ & epp & 2.38 & 2.38 & - & - & - & - & - & - & - & - \\
\hline $\mathrm{BM}$ & esf (133) & $7.32 .10^{-2}$ & $1.47 .10^{-1}$ & 30.9 & 0.587 & $1.43 .10^{-3}$ & 50.3 & $\mathrm{ME}$ & $7.40 .10^{-1}$ & 0.816 & 0.377 \\
\hline FM & $\exp (130)$ & $3.55 .10^{-3}$ & $3.49 .10^{-2}$ & 17.1 & 0.596 & $3.93 .10^{-5}$ & 89.8 & MA & $9.00 .10^{-2}$ & 0.955 & 0.363 \\
\hline $\mathrm{SM}$ & $\exp (138)$ & $3.80 .10^{-3}$ & $4.19 .10^{-2}$ & 21.3 & 0.521 & $1.52 .10^{-4}$ & 90.9 & MA & $1.90 .10^{-1}$ & 0.899 & 0.415 \\
\hline$\% \mathrm{~F}$ & $\exp (121)$ & $1.29 .10^{-1}$ & 1.07 & 19.5 & 0.851 & $1.52 .10^{-2}$ & 87.9 & MA & 7.55 & 0.857 & 0.316 \\
\hline M100 & epp & $2.30 .10^{-1}$ & $2.30 .10^{-1}$ & - & - & - & - & - & - & - & - \\
\hline \multicolumn{12}{|c|}{$\gamma(h)$ simple - soil } \\
\hline$\# \mathrm{P}$ & epp & 3.79 .10 & 3.79 .10 & - & - & - & - & - & - & - & - \\
\hline $\mathrm{OM}$ & epp & 4.87 & 4.87 & - & - & - & - & - & - & - & - \\
\hline $\mathrm{pH}$ & gau (130) & $2.24 .10^{-2}$ & $5.25 .10^{-2}$ & 13.6 & 0.399 & $1.57 .10^{-4}$ & 57.3 & $\mathrm{ME}$ & $6.40 .10^{-1}$ & 0.881 & 0.333 \\
\hline $\mathrm{K}$ & epp & $2.06 .10^{-1}$ & $2.06 .10^{-1}$ & - & - & - & - & - & - & - & - \\
\hline $\mathrm{Ca}$ & epp & 1.90 .10 & 1.92 .10 & - & - & - & - & - & - & - & - \\
\hline $\mathrm{Mg}$ & epp & 1.50 .10 & 1.50 .10 & - & - & - & - & - & - & - & - \\
\hline $\mathrm{H}+\mathrm{Al}$ & epp & 3.31 .10 & 3.31 .10 & - & - & - & - & - & - & - & - \\
\hline SB & epp & 6.36 .10 & 6.36 .10 & - & - & - & - & - & - & - & - \\
\hline $\mathrm{T}$ & epp & 2.75 .10 & 2.75 .10 & - & - & - & - & - & - & - & - \\
\hline $\mathrm{V} \%$ & epp & 9.14 .10 & 9.14 .10 & - & - & - & - & - & - & - & - \\
\hline \multicolumn{12}{|c|}{$\gamma(h)$ crossed - plant $x$ soil } \\
\hline$\# \mathrm{CY}=\mathrm{f}(\mathrm{PH})$ & gau (116) & $1.00 .10^{-1}$ & 3.60 .10 & 22.9 & 0.328 & $1.83 .10^{3}$ & 99.7 & MA & 8.65 & 0.989 & 0.792 \\
\hline$\# \mathrm{CY}=\mathrm{f}(\mathrm{SD})$ & esf (120) & $1.00 .10^{-1}$ & $3.05 .10^{2}$ & 30.7 & 0.431 & $7.22 .10^{4}$ & 100.0 & MA & 5.45 & 0.916 & 0.726 \\
\hline$\# \mathrm{CY}=\mathrm{f}(\mathrm{RB})$ & $\begin{array}{l}\text { gau } \\
\text { (2015) }\end{array}$ & 1.51 .10 & $2.93 .10^{2}$ & 28.9 & 0.629 & $3.20 .10^{4}$ & 94.8 & MA & 5.83 & 0.958 & 0.753 \\
\hline$\# \mathrm{CY}=\mathrm{f}(\mathrm{BM})$ & gau (53) & 3.22 .10 & $1.42 .10^{2}$ & 33.6 & 0.776 & $3.84 .10^{3}$ & 77.4 & $\mathrm{AL}$ & -2.84 & 0.943 & 0.752 \\
\hline$\# \mathrm{CY}=\mathrm{f}(\% \mathrm{~F})$ & esf (130) & $-1.00 .10^{-1}$ & $-2.73 .10^{2}$ & 27.5 & 0.819 & $7.48 .10^{3}$ & 100.0 & MA & -1.43 & 1.000 & 0.783 \\
\hline
\end{tabular}

(a) $\# \mathrm{CY}=$ seed cotton productivity, $\# \mathrm{PP}=$ plant population, $\mathrm{PH}=$ plant height, $\mathrm{SD}=$ stem diameter, $\mathrm{RB}=$ number of reproductive branches, $\mathrm{BP}=$ number of bolls per plant, $\mathrm{BM}=$ boll mass, $\mathrm{FM}=$ fiber mass per boll, $\mathrm{SM}=$ seed mass per boll, $\% \mathrm{~F}=$ percentage of fiber, $\mathrm{M} 100=100$-seed mass, $\# \mathrm{P}=$ phosphorus, $0 \mathrm{M}=$ organic matter, $\mathrm{pH}=$ potential of hydrogen, $\mathrm{K}=$ potassium, $\mathrm{Ca}=$ calcium, $\mathrm{Mg}=$ magnesium, $\mathrm{H}+\mathrm{Al}=$ potential acidity, $\mathrm{SB}=$ sum of bases, $\mathrm{T}=\mathrm{cation}$ exchange capacity and $\mathrm{V} \%=$ base saturation; \# = attribute worked with the data residue; parentheses after the model = number of pairs in the first lag; ${ }^{(b)}$ esf $=s p h e r i c a l$, epp $=$ pure nugget effect, exp = exponential and gau = Gaussian; (c) $\mathrm{SQR}=$ sum of squared residuals; (d) SDE = spatial dependence evaluator, where $M A=$ very high, $M E=$ intermediate and $A L=$ high.

substantial quality. Its geostatistical range $(13.6 \mathrm{~m})$ indicated that, for the property in question, soil samples should be taken in grids of $185 \mathrm{~m}^{2}(13.6$ $\mathrm{x} 13.6 \mathrm{~m})$. The low value of the parameter is associated with the extrinsic variability, related to the practices of soil management, which contributed to the reduction of the range (Silva et al., 2007). The geostatistical data for the $\mathrm{pH}$ behaved similarly, except for the spherical models, to the results evidenced by Johnson et al. (2002) and Motomiya et al. (2011), where the latter obtained a low spatial correlation (0.330) and intermediate spatial dependence (40.0\%), as well as the spherical model described by Sana et al. (2014) and by Zonta et al. (2014).

In general, the semivariogram ranges were between $13.6(\mathrm{pH})$ and $31.8 \mathrm{~m}(\mathrm{PH})$, indicating that for specific and localized management, the reference values used in precision agriculture should not be less than $13.6 \mathrm{~m}$ (Table 5), because they represent the distance within which the values of a given property have a spatial correlation with each other, since the range value can influence 
the quality of the estimate, since it determines the number of values used in the interpolation. Thus, estimates obtained by kriging interpolation using the highest range values tend to be more reliable, presenting maps that better represent reality (Dalchiavon et al., 2011). On the other hand, the smaller the ranges, the more important will be the interpolation and, therefore, semivariograms should be more precise, especially at small distances (Vieira et al., 2010). Another aspect to be mentioned is that all the obtained ranges exceeded the values of the spacings between the samplings, suggesting that the samples are correlated with each other, allowing interpolations (Vieira et al., 2007).
The kriging maps obtained from modeling the semivariograms and illustrated in Figures 2 and 3, although some have intricate aspects, are directly similar to each other (except for \%F), that is, in regions where the values are smaller for $£ \mathrm{CY}$, for example, are the same regions where the lowest values are found for the other evaluated attributes, as well as for the regions of higher values between them. This behavior trend concentrated, with some exceptions, the highest values in the central regions and partly on the sides of the map, while the lowest values were present in the marginal regions of the maps, where the yields were lower than the average of the crop. This fact can also be
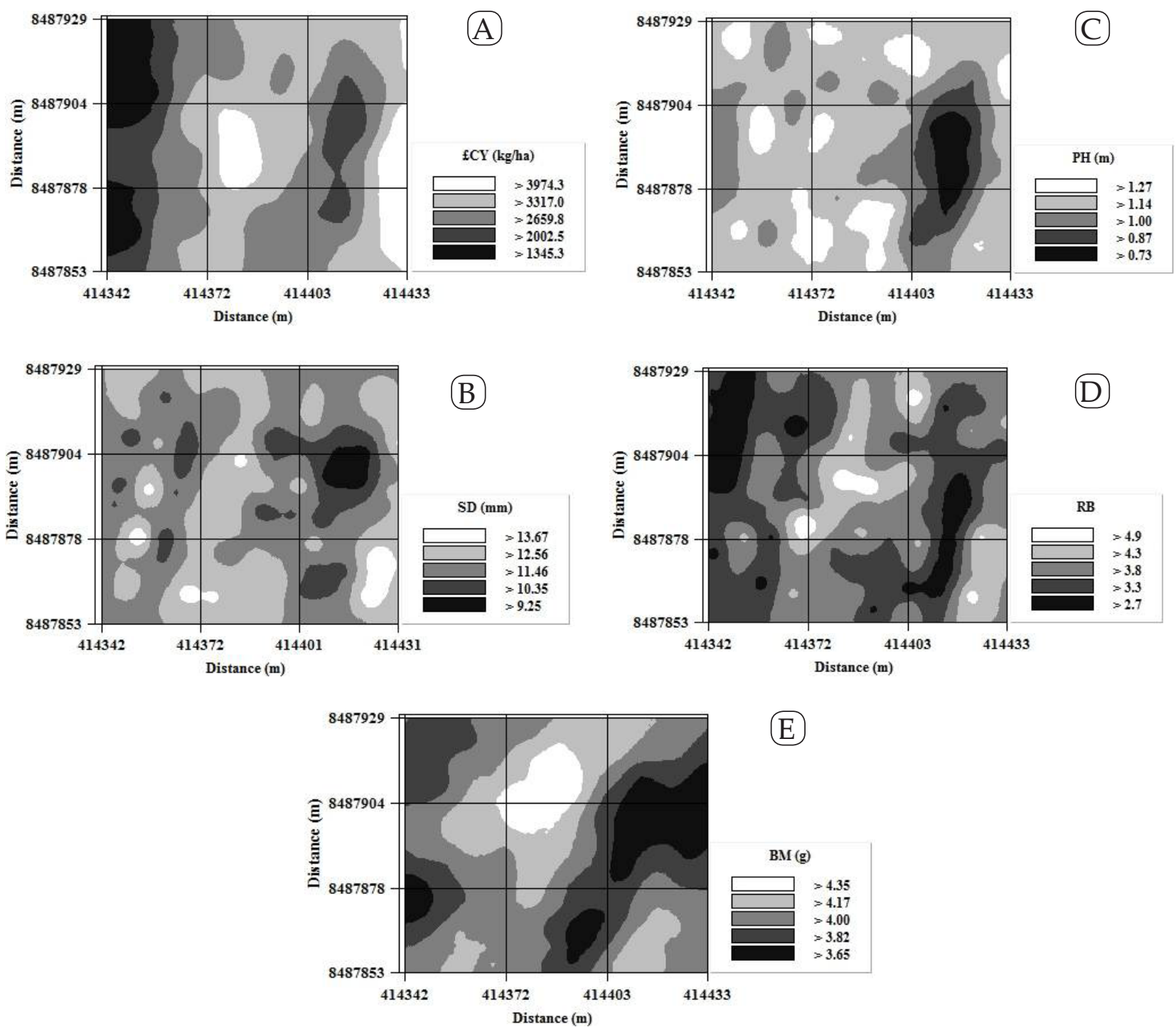

Figure 2 - Kriging maps of production attributes of Gossypium hirsutum L. in a Typic Tropustox under no-till system. Campo Novo do Parecis (MT), 2015. 

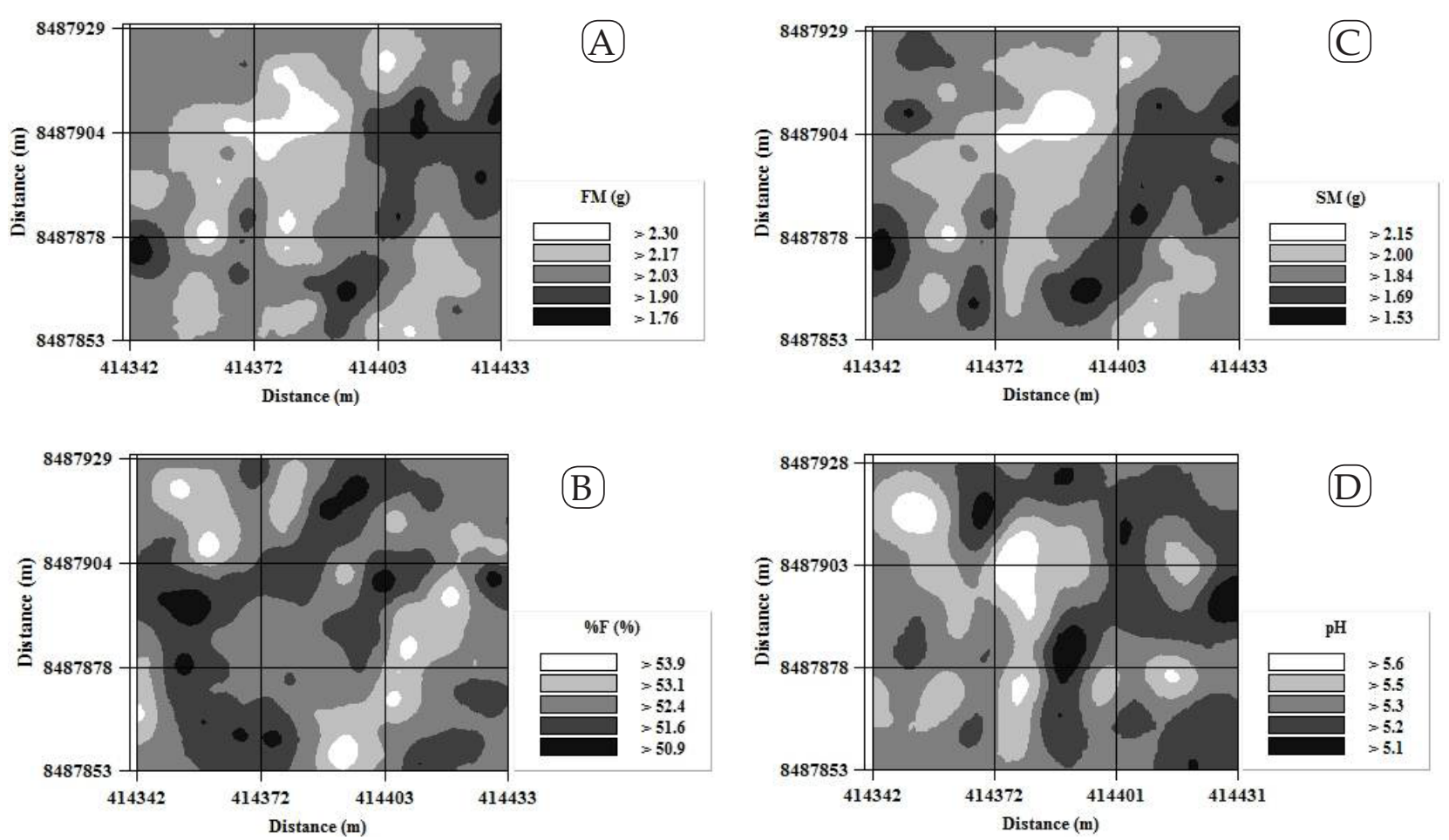

Figure 3 - Kriging maps of production attributes of Gossypium hirsutum L. and of properties of a Typic Tropustox under no-till system. Campo Novo do Parecis (MT), 2015.
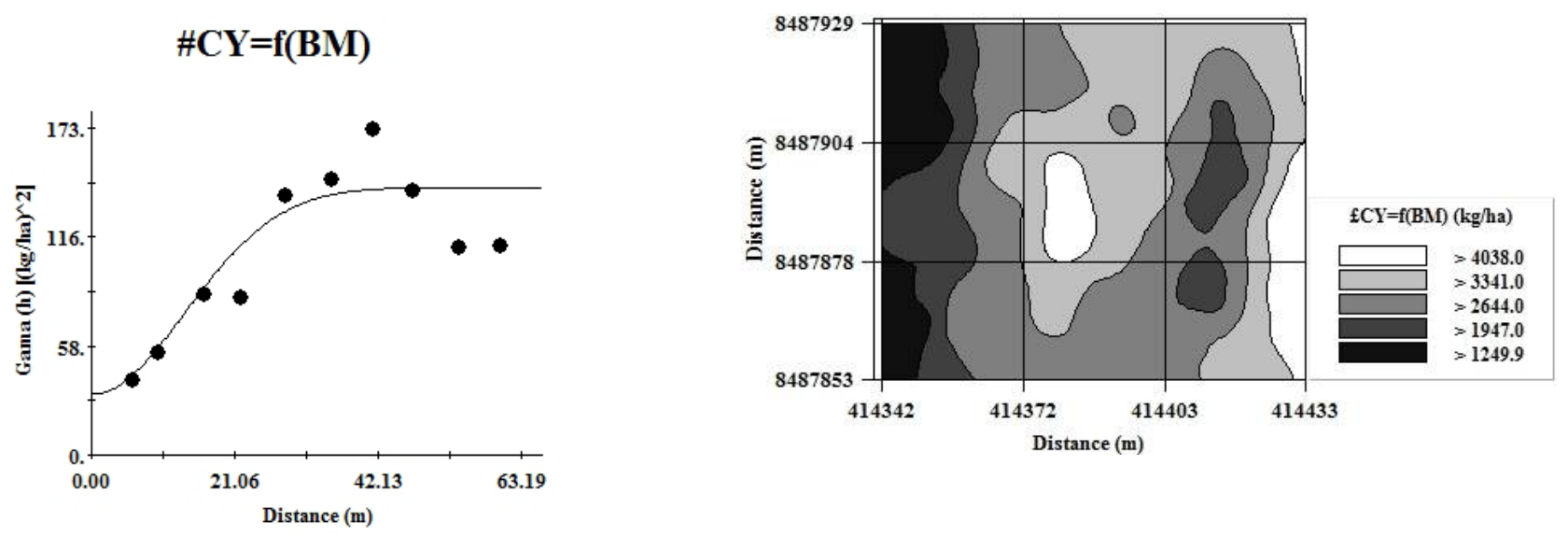

Figure 4 - Cross semivariogram and cokriging map of $£ C Y$ according to BM of a Typic Tropustox under no-till system. Campo Novo do Parecis (MT), 2015. 

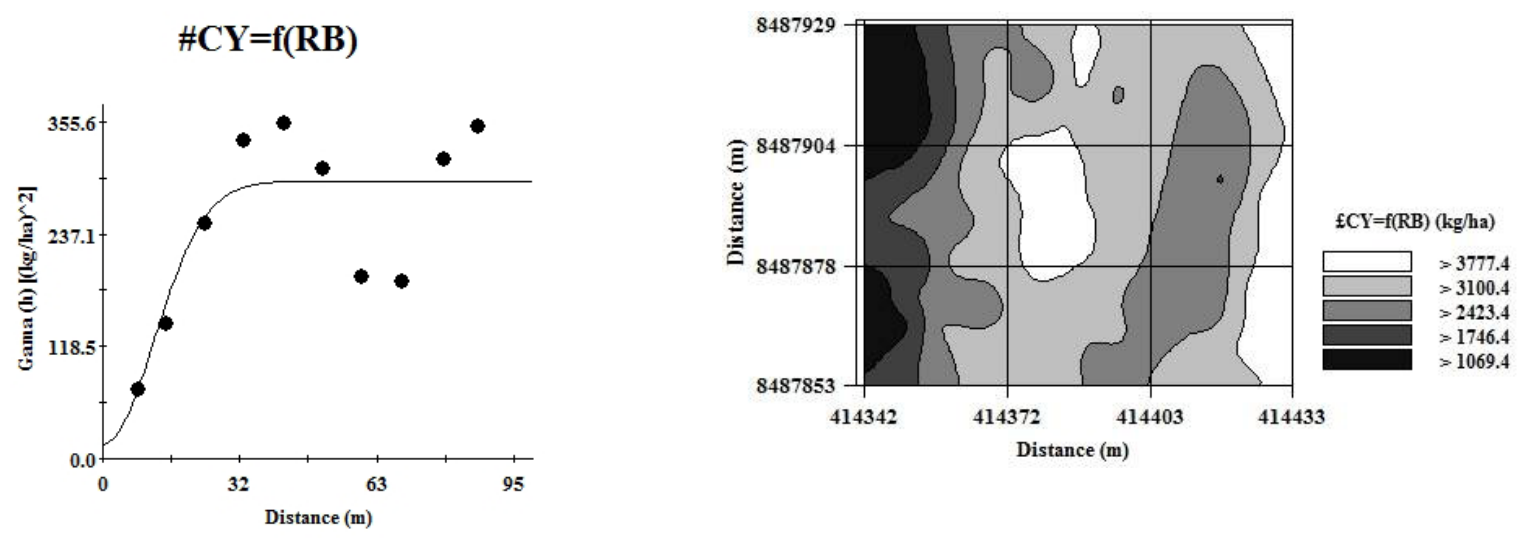

Figure 5 - Cross semivariogram and cokriging map of $£ C Y$ according to RB of a Typic Tropustox under no-till system. Campo Novo do Parecis (MT), 2015.

observed in Figures 4 and 5, which present, by means of the existing direct relationship, the cross semivariograms and their respective cokriging maps between the $£ C Y$ and the $B M$ and $R B$.

In this context, we recommend to investigate the factors that affect crop productivity, beginning with the history of management, fertilization, crop rotation and productivity obtained in each crop. Thus, when heterogeneous behavior is identified, applications of inputs, or regionalized management of soil and crop, can be made with variable rates. Nevertheless, when factors that alter productivity cannot be corrected due to the intrinsic characteristics of the soil, it is advisable to create management zones and treat them differently, according to the productive potential of each site (Torbett et al., 2007; Walton et al., 2008; Sana et al., 2014). Following these recommendations, it was possible to verify that in the left vertical third, where there were the lowest yields, it was precisely where rainwater accumulated (Figure 1), because it is border, during the establishment phase of the crop, which reflected in the death of a significant amount of plants. This may have contributed to the lack of spatial dependence of PP data (Table 5).

In relation to the soil $\mathrm{pH}$, in more than $50 \%$ of the area $\mathrm{pH}$ was less than 5.5 (Figure 3). This may represent a problem since Carvalho et al. (2011) reported that soil acidity negatively affects root development and growth of the cotton plant, directly affecting productivity. There are evidences of reduced productivity in soils with $\mathrm{pH}$ below this threshold.

However, it was not possible to model the cross-semivariogram between the \#CY and the $\mathrm{pH}$, although cross-semivariograms were obtained between the productive attributes of cotton, as previously mentioned (Table 5, Figures 4 and 5). The decreasing order of their spatial correlation coefficients $\left(\mathrm{r}^{2}\right)$ was: 1$)$ \#CY $\left.=\mathrm{f}(\% \mathrm{~F})(0.819), 2\right)$ \#CY $=\mathrm{f}(\mathrm{BM})(0.776), 3) \# \mathrm{CY}=\mathrm{f}(\mathrm{RB})(0.629), 4) \# \mathrm{CY}=\mathrm{f}(\mathrm{SD})$ $(0.431)$ and 5$) \# C Y=f(P H)(0.328)$. From these, the numbers 2 to 5 could be perfectly used to estimate the seed cotton productivity quickly due to the great ease in determining the independent variables (PH, SD, RB and BM) still in the field. In this context, the two cross-linked semivariograms with higher $r^{2}[\# C Y=f(B M)$ and $\# C Y=f(R B)]$ were Gaussian, both with high coefficient of spatial determination (0.776 and 0.629 , respectively), as observed in Table 5 and Figures 4 and 5. Thus, from the spatial point of view, there was a direct spatial correlation of \#CY with BM and RB.

In Figures 2 and 4, cokriging \#CY $=\mathrm{f}(\mathrm{BM})$ showed, in sites with lower values of BM $(3.65-4,00)$, the lowest £CY (1345.3-2659.8 kg ha-1). Conversely, in regions with higher $\mathrm{BM}$ values (> 4.00), the highest ECY (2659.8-3974.3 $\left.\mathrm{kg} \mathrm{ha}^{-1}\right)$ were found. Similarly, in Figures 2 and 5, it was observed that regions with the lowest values of RB (2.7-3.8) were precisely the sites with the lowest $£ C Y$ values (1345.3-2659.8 $\left.\mathrm{kg} \mathrm{ha}^{-1}\right)$. Higher values of $£ C Y\left(>2659.8 \mathrm{~kg} \mathrm{ha}^{-1}\right)$ were mapped 
where RB was above 1.00. Such behavior addresses the direct relationship between these production attributes, the result of their interdependence. In this sense, when the intention is to increase the productivity of seed cotton, agronomic management that stimulates the production of branches and reproductive bolls must be adopted in the property, since this study clearly demonstrates the implication of $\mathrm{BM}$ and $\mathrm{RB}$ on the productivity of seed cotton.

\section{CONCLUSIONS}

The variability expressed by the coefficient of variation was predominantly low to moderate for all soil chemical properties and cotton production variables.

The absence of spatial dependence in soil chemical properties, except for $\mathrm{pH}$, indicated that spatial variations should beconsidered for soilsampling design.
The kriging maps for the production attributes of cotton revealed that these variables have similar patterns of spatial distribution in the crop.

The productive attributes of the direct relationship, both linear and spatial, with the productivity of seed cotton were the number of reproductive branches and the boll mass.

\section{ACKNOWLEDGEMENTS}

The authors would like to thank the Research Group in Phytotechnology (GPF) of the Instituto Federal de Educação Ciência e Tecnologia de Mato Grosso (IFMT), Campo Novo do Parecis MT Brazil, for funding and assistance during the assay. The authors are also grateful to the Fundação de Apoio à Pesquisa do Estado de Mato Grosso / Foundation for Research Support of the State of Mato Grosso (FAPEMAT - Process №. 157188/2014) by granting scientific training scholarship and financial assistance for research.

\section{REFERENCES}

Alves, M.C.; Carvalho, M.P.; Lima, R.C. \& Vanzela, S.L. (2009) - Ambiente de produção para a cana-de-açúcar cultivada nas propriedades agrícolas da Usina Vale do Paraná S/A Álcool e Açúcar. Ilha Solteira. 107 p.

Carvalho, M.A.C. de; Paulino, H.B.; Furlani Júnior, E.; Buzetti, S.; Sá, M.E. de \& Athayde, M.L.F. de (2001) - Uso da adubação foliar nitrogenada e potássica no algodoeiro. Bragantia, vol. 60, n. 3, p. 239-244. http:// dx.doi.org/10.1590/S0006-87052001000300011

Carvalho, M.C.S.; Ferreira, G.B. \& Staut, L.A. (2011) - Nutrição, calagem e adubação do algodoeiro. In: Freire, E.C. (Ed.) - Algodão no cerrado do Brasil. 2nd ed. Aparecida de Goiânia: Mundial Gráfica. 1082 p.

CONAB (2017) - Acompanhamento da safra brasileira: grãos - quarto levantamento, janeiro 2017. Brasília, DF: CONAB. 158 p.

Dalchiavon, F.C.; Carvalho, M.P.; Coletti, A.J.; Caione, G.; Silva, A.F. \& Andreotti, M. (2012) - Correlação linear entre componentes da produção e produtividade do arroz de terras altas em sistema plantio direto. Semina: Ciências Agrárias, vol. 33, n. 5, p. 1629-1642. http://dx.doi.org/10.5433/1679-0359.2012v33n5p1629

Dalchiavon, F.C. \& Carvalho, M.P. (2012) - Correlação linear e espacial dos componentes de produção e produtividade da soja. Semina: Ciências Agrárias, vol.33, n. 2, p. 541-552. http://dx.doi.org/10.5433/16790359.2012v33n2p541

Dalchiavon, F.C.; Carvalho, M.P.; Montanari, R. \& Andreotti, M. (2013a) - Sugar cane productivity correlated with physical-chemical attributes to create soil management zone. Revista Ceres, vol. 60, n. 5, p. 706-714. http://dx.doi.org/10.1590/S0034-737X2013000500015

Dalchiavon, F.C.; Carvalho, M.P.; Montanari, R.; Andreotti, M. \& Dal Bem, E.A. (2013c) - Sugarcane trash management assessed by the interaction of yield with soil properties. Revista Brasileira de Ciência do Solo, vol. 37, n. 6, p. 1709-1719. http://dx.doi.org/10.1590/50100-06832013000600027 
Dalchiavon, F.C.; Carvalho, M.P.; Montanari, R. \& Andreotti, M. (2013b) - Strategy of specification of management areas: rice grain yield as related to soil fertility. Revista Brasileira de Ciência do Solo, vol. 37, n. 1, p. 45-54. http://dx.doi.org/10.1590/S0100-06832013000100005

Dalchiavon, F.C.; Carvalho, M.P.; Nogueira, D.C.; Romano, D.; Abrantes, F.L.; Assis, J.T. \& Oliveira, M.S. (2011) - Produtividade da soja e resistência mecânica à penetração do solo sob sistema plantio direto no cerrado brasileiro. Pesquisa Agropecuária Tropical, vol. 41, n. 1, p. 8-19. http://dx.doi.org/10.5216/pat.v41i1.8351

Dalchiavon, F.C.; Montanari, R.; Andreotti, M.; Dallacort, R. \& Souza, M.F.P. (2015) - Relationship between sunflower productivity and soil's chemical properties by geo-statistical techniques. African Journal of Agricultural Research, vol. 10, n. 35, p. 3525-3532. http://dx.doi.org/10.5897/AJAR2014.9472

Guo, W.; Maas, S.J. \& Bronson, K.F. (2012) - Relationship between cotton yield and soil electrical conductivity, topography, and landsat imagery. Precision Agriculture, vol.13, n. 6, p. 678-692. http://dx.doi.org/10.1007/ s11119-012-9277-2

Henrique, F.H. \& Laca-Buendía, J.P. (2010) - Comportamento morfológico e agronômico de genótipos de algodoeiro no município de Uberaba - MG. FAZU em Revista, vol. 7, n. 1, p. 32-36.

Johnson, R.M.; Downer, R.G.; Bradow, J.M.; Bauer, P.J. \& Sadler, E.J. (2002) - Variability in cotton fiber yield, fiber quality and soil properties in a Southeastern Coastal Plain. Agronomy Journal, vol. 94, n. 6, p. 13051316. http://dx.doi.org/10.2134/agronj2002.1305

Kaneko, F.H.; Leal, A.J.F.; Dias, A.; Anselmo, J.L.; Buzetti, S.; Dal Bem, E.A.; Gitti, D. de C. \& Nascimento, V. (2014) - Resposta do algodoeiro em cultivo adensado a doses de nitrogênio, fósforo e potássio. Revista Agrarian, vol. 7, n. 25, p. 382-389.

Molin, J.P.; Vieira Junior, P.A.; Dourado Neto, D.; Faulin, G. di C. \& Mascarin, L. (2007) - Variação espacial na produtividade de milho safrinha devido aos macronutrientes e à população de plantas. Revista Brasileira de Milho e Sorgo, vol. 6, n. 3, p. 309-324. http://dx.doi.org/10.18512/1980-6477/rbms.v6n3p309-324

Montanari, R.; Carvalho, M.P.; Andreotti, M.; Dalchiavon, F.C.; Lovera, L.H. \& Honorato, M.A.O. (2010) - Aspectos da produtividade do feijão correlacionados com atributos físicos do solo sob elevado nível tecnológico de manejo. Revista Brasileira de Ciência do Solo, vol. 34, n. 6, p. 1811-1822. http://dx.doi.org/10.1590/ S0100-06832010000600005

Montanari, R.; Carvalho, M.P.; Silva Junior, C.A.; Corrêa, A.R.; Dalchiavon, F.C. \& González, A.P. (2013) Relations between the yield of bean (Phaseolus vulgaris L.) and chemical attributes of an Acrustox under no-tillage. Journal of Soil Science and Plant Nutrition, vol. 13, n. 2, p. 367-379. http://dx.doi.org/10.4067/S071895162013005000030

Mooney, D.F.; Roberts, R.K.; English, B.C.; Lambert, D.M.; Larson, J.A.; Velandia, M.; Larkin, S.L.; Marra, M.C.; Martin, S.W.; Mishra, A.; Paxton, K.W.; Rejesus, R.; Segarra, E.; Wang, C. \& Reeves, J.M. (2010) Precision farming by cotton producers in twelve southern states: Results from the 2009 southern cotton precision farming survey. Knoxville: University of Tennessee, Department of Agricultural and Resource Economics. 70 p. Research Reports 91333.

Motomiya, A.V.A.; Molin, J.P.; Motomiya, W.R. \& Vieira, S.R. (2011) - Spatial variability of soil properties and cotton yield in the Brazilian Cerrado. Revista Brasileira de Engenharia Agrícola e Ambiental, vol. 15, n. 10, p. 996-1003. http://dx.doi.org/10.1590/S1415-43662011001000002

Raij, B.V.; Andrade, J.C.; Cantarella, H. \& Quaggio, J.A. (2001) - Análise química para avaliação da fertilidade de solos tropicais. Campinas: Instituto Agronômico. 285 p.

Raij, B.V.; Cantarella, H.; Quaggio, J.A. \& Furlani, A.M.C. (1997) - Recomendações de adubação e calagem para o Estado de São Paulo. Campinas: Instituto Agronômico. 285 p.

Sana, R.S.; Anghinoni, I.; Brandão, Z.N. \& Holzschuh, M.J. (2014) - Variabilidade espacial de atributos físicoquímicos do solo e seus efeitos na produtividade do algodoeiro. Revista Brasileira de Engenharia Agrícola e Ambiental, vol. 18, n. 10, p. 994-1002. http://dx.doi.org/10.1590/1807-1929/agriambi.v18n10p994-1002

Santos, F.C. dos; Albuquerque Filho, M.R. de; Novais, R.F. de; Ferreira, G.B.; Carvalho, M. da C.S. \& Silva Filho, J.L. da (2012) - Fontes, doses e formas de aplicação de fósforo para o algodoeiro no Cerrado da Bahia. Revista Ceres, vol. 59, n. 4, p. 537-543. http://dx.doi.org/10.1590/S0034-737X2012000400015

Silva, F.M.; Souza, Z.M.; Figueiredo, C.A.P.; Marques Júnior, J. \& Machado, R.V. (2007) - Variabilidade espacial de atributos químicos e de produtividade na cultura do café. Ciência Rural, vol. 37, n. 2, p. 401407. http://dx.doi.org/10.1590/S0103-84782007000200016 
Stewart, C.; Boydell, B. \& McBratney, A. (2005) - Precision decisions for quality cotton: A guide to site-specific cotton crop management. Sidney: University of Sydney. 107 p.

Teixeira, I.R.; Kikuti, H. \& Borém, A. (2008) - Crescimento e produtividade de algodoeiro submetido a cloreto de mepiquat e doses de nitrogênio. Bragantia, vol. 67, n. 4, p. 891-897. http://dx.doi.org/10.1590/5000687052008000400011

Torbett, C.J.; Roberts, R.K.; Larson, J.A. \& English, B.C. (2007) - Perceived importance of precision farming technologies in improving phosphorous and potassium efficiency in cotton production. Precision Agriculture, vol. 8, n. 3, p. 127-137. http://dx.doi.org/10.1007/s11119-007-9033-1

Vieira, S.R.; Carvalho, J.R.P. \& González, A.P. (2010) - Jack knifing for semivariogram validation. Bragantia, vol. 69, n. supl. 0, p. 97-105. http://dx.doi.org/10.1590/S0006-87052010000500011

Vieira, V.A.S.; Mello, C.R. \& Lima, J.M. (2007) - Variabilidade espacial de atributos físicos do solo em uma microbacia hidrográfica. Ciência e Agrotecnologia, vol. 31, n. 5, p. 1477-1485. http://dx.doi.org/10.1590/S141370542007000500031

Walton, J.C.; Lambert, D.M.; Roberts, R.K.; Larson, J.A.; English, B.C.; Larkin, S.L.; Martin, S.W.; Marra, M.C.; Paxton, K.W. \& Reeves, J.M. (2008) - Adoption and abandonment of precision soil sampling in cotton production. Australian Journal of Agricultural and Resource Economics, vol. 33, n. 3, p. 428-448.

Zonta, J.H.; Brandão, Z.N.; Medeiros, J. da C.; Sana, R.S. \& Sofiatti, V. (2014) - Variabilidade espacial da fertilidade do solo em área cultivada com algodoeiro no Cerrado do Brasil. Revista Brasileira de Engenharia Agrícola e Ambiental, vol. 18, n. 6, p. 595-602. 